Jurnal Ilmu dan Teknologi Kesehatan

Vol 6, No 1, September 2018,

ISSN: 2338-9095 (Print)

ISSN: 2338-9109 (online)

\title{
Feldenkrais Exercise Mempangaruhi Peningkatan Aktivitas Fungsional Lebih Efektif daripada William Flexion Exercise terhadap Orang dengan Low Back Pain Miogenik
}

\author{
Yuda Saputra ${ }^{1}$, Ahmad Syakib ${ }^{2}$ \\ Poltekkes Kemenkes Jakarta III \\ yudasaputra560@gmail.com
}

\author{
Artikel history \\ Dikirim, Jun $12^{\text {th }}, 2018$ \\ Ditinjau, Aug 9 ${ }^{\text {th }}, 2018$ \\ Diterima, Aug $26^{\text {th }}, 2018$
}

\begin{abstract}
ABSTACT
Background : Low Back Pain Miogenik is a lower back pain caused by muscle tension with avery high frequency of cases in workers. This research is done to identify the difference of influence between the approach of William Flexion Exercise and Feldenkrais exercise to functional activity inpatient low back pain miogenik because of the many cases that happened.. Methods : The type of research used is experimental research, research design used is a quasi experiment that compares between two different things. The targets of this study were factory workers with a sampel of 34 people divided into two groups. Result: Based on the result ofhypothesis paired t-test result p-value 0.000 shows both treatment there is significant improvement to functional activity. While on thetest Independentt-test results seen from the mean feldenkrais exercise 8.13 and william flexion exercise 3.25 concluded feldenkrais exercise more up than william flexion exercise.
\end{abstract}

Keywords : Low Back Pain Miogenik, Feldenkrais Exercise, William Flexion Exercise

\begin{abstract}
ABSTRAK
Latar Belakang : Low Back Pain Miogenik adalah nyeri punggung bawah yang disebabkanoleh ketegangan otot dengan frekuensi kasus yang sangat banyak pada pekerja. Penelitian ini dilakuakan untuk mengidentifikasi perbedaan pengaruh antara pemberian pendekatan William Flexion Exercise dan Feldenkrais exercise terhadap aktivitas fungsional pada penderita low back pain miogenik karena banyaknya kasus yang terjadi. Metode : Jenis penelitian yang digunakan adalah penelitian eksperimen, desain penelitian yang digunakan adalah eksperimen semu yang membandingkan perbedaan pengaruh pada dua kelompok dengan perlakuan dari dua intervensi yang berbeda. Sasaran pada penelitian ini adalah para pekerja pabrik dengan sampel sebanyak 32 orang yang dibagi menjadi dua kelompok. Hasil : Berdasarkan hasil uji hipotesis paired t-test dihasilkan $p$-value 0,000 menunjukkan kedua perlakuan terjadi peningkatan yang signifikan terhadap aktifitas fungsional. Sedangkan pada hasil uji Independent t-test dilihat dari hasil
\end{abstract}


9 Jurnal Ilmu dan Teknologi Kesehatan, Vol 6 Nomor 1, September 2018, hlm : 8 - 14

mean feldenkrais exercise 8,13 dan william flexion exercise 3,25 disimpulkan feldenkrais exercise lebih naik dibanding william flexion exercise.

Kata Kunci : Low Back Pain Miogenik, Feldenkrais exercise, William Flexion Exerci

\section{PENDAHULUAN}

Low Back Pain (LBP) merupakan kasus yang sering sekali dijumpai dimasyarakat. Di Indonesia LBP sering disebut sebagai nyeri pinggang yang efeknya dapat menyebabkan ketidakmampuan dalam mengerjakan sesuatu. LBP sering terjadi pada lansia, ibu hamil, pekerja pabrik, dll (Duthey 2013). Pada sebuah penelitian cross- sectional pada pekerja industri di Mumbai menunjukan bahwa masalah muskuloskeletal yang paling banyak terjadi pada pekerja industri disana adalah LBP sebanyak 92,4\%, shoulder pain sebanyak 64,8\%, nyeri lutut sebanyak $31 \%$, dan nyeri tangan sebanyak 25\% dari keseluruhan masalah muskuloskeletal yang terjadi (Dabholkar et al. 2014).

\section{Low Back Pain Miogenik disebabkan} oleh adanya spasme pada otot yang mana dapat menimbulkan penderita merasakan nyeri. Spasme otot yang berkepanjangan dapat menimbulkan vasokontriksi pembuluh darah yang mengakibatkan iskemia, sehingga penderita akan membatasi adanya gerakan yang dapat menimbulkan nyeri (Lee, et al. 2016). Fisioterapi memegang peranan penting dalam menangani gangguan gerak dan fungsi tubuh sepanjang rentang daur hidup manusia, termasuk juga dalam penanganan kasus LBP miogenik. Hal tersebut sesuai dengan definisi fisioterapi yang tertuang pada Pasall dalam Permenkes 65 tahun 2015.

Konsep latihan dengan pendekatan William Flexion Exercise merupakan salah satu latihan yang bisa diterapkan oleh fisioterapis dalam meningkatkan aktivitas fungsional. William Flexion Exercise adalah jenis latihan terdiri dari enam bentuk gerakan yang dirancang untuk membuka foramen intervertebralis dan sendi faset, mengulur otot fleksor hip dan ekstensor lumbal, menguatkan otot abdominalis dan otot gluteal serta meningkatkan mobilitas jaringan ikat bagian posterior lumbosakral joint (Borestein et al. 2004). Menurut penelitian yang dilakukan oleh Kusuma (2015) mengemukakakan bahwa william flexion exercise cocok untuk memperbaiki hubungan antar sendi dan latihan yang baik untuk low back pain miogenik. 
Selain dengan pendekatan William Flexion Exercise, ada juga penanganan LBP miogenik dengan metode Feldenkrais exercise. Feldenkrais exercise adalah latihan yang dilakukan untuk meningkatkan relaksasi dan menitikberatkan pemusatan fikiran, emosi, penglihatan dan pengaturan pola pernafasan. Feldenkrais exercise dilakukan untuk meningkatkan dan aktivasi otot bagian dalam dari lumbal dan meningkatkan stabilitas pada jaringan yang ada di dalamnya (Fonow et al. 2016). Sesuai penelitian yang dilakukan oleh Mohan (2016) mengatakan bahwa dengan latihan menggunakan feldenkraise dapat meningkatkan relaksasi otot bagian paralumbal dan memberikan aktivasi pada otot pada deep ekstensor sehingga sangat efektif untuk low back pain myogenik.

Pada berbagai literatur ada banyak latihan untuk menangani LBP miogenik, tapi masih sulit ditemukan latihan mana yang lebih efektif, sehingga peneliti ingin melakukan penelitian apakah terdapat perbandingan pengaruh pemberian Feldenkrais exercise dan William Flexion Exercise terhadap aktivitas fungsional pada Low Back Pain Miogenik di PT. Langgeng Karya Perkasa Bantar Gebang.

\section{METODE}

Jenis penelitian yang digunakan adalah penelitian eksperimen, desain penelitian yang digunakan adalah eksperimen semu yang membandingkan perbedaan pengaruh pada dua kelompok dengan perlakuan dari dua intervensi yang berbeda.

Penelitian ini dilaksanakan di PT. Langgeng Karya Perkasa Bantar Gebang pada bulan April 2018 hingga Juni 2018. Serta penyusunan proposal hingga penyusunan skripsi dilakukan pada Desember 2017 hingga Juli 2018.

Populasi dalam penelitian ini adalah karyawan yang bekerja di PT. Langgeng Karya Perkasa Bantar Gebang. Sampel 30 orang yang kemudian dibagi menjadi dua kelompok, yaitu 15 orang kelompok perlakuan Feldenkrais Exercise dan 15 orang kelompok perlakuan William Flexion Exercise.

Kriteria Inklusi, meliputi; Pria dan wanita yang mengalami Low Back Pain Miogenik dengan tingkat nyeri tekan $\leq 5$ $\mathrm{kg}$ dengan algometer digital, kooperatif dan dapat berkomunikasi dengan baik,Serta bersedia menjadi sampel pada penelitian ini.

Kriteria Eksklusi, meliputi; Memiliki riwayat kelainan pada tulang belakang, sedang menderita fraktur tulang belakang, dan sedang menjalani terapi terkait nyeri tulang belakang. 
11 Jurnal Ilmu dan Teknologi Kesehatan, Vol 6 Nomor 1, September 2018, hlm : 8 - 14

Prosedur pengumpulan data yang dilakukan yaitu, menyebar kuesioner dan menentukan sampel yang sesuai dengan inklusi untuk dijadikan responden peneltian, kemudian membagi responden kedalam dua kelompok, yaitu kelompok perlakuan William flexion exercise sebanyak 15 responden dan kelompok perlakuan Feldenkrais exercise sebanyak 15 responden. Selanjutnya, dilakukan pengukuran dengan menggunakan alat ukur oswestry disability index (ODI) untuk memperoleh hasil pre intervensi. Kemudian memberikan intervensi sesuai dengan kelompok perlakuan.

Prosedur penatalaksanaan pada kelompok perlakuan William flexion exercise diawali dengan memposisikan responden berbaring senyaman mungkin kemudian menjelaskan manfaat pemberian William flexion exercise kepada responden. Selanjutnya dilakukan gerakan latihan meliputi ekstensi pada posisi berdiri, fleks pada posisi supine dan fleksi pada posisi duduk.

Pada kelompok perlakuan Feldenkrais exercise, prosedur pelaksanaan diawali dengan memposisikan responden berbaring senyaman mungkin, kemudian menjelaskan manfaat pemberian Feldenkrais exercise kepada responden, selanjutnya dilakukan gerakan latihan meliputi Cross your right leg over the left knee, lift arm and leg, dan Prone with bent knee.

Setelah diberikan intervensi, dilakukan evaluasi aktifitas fungsional dengan menggunakan alat ukur oswestry disability index (ODI), data sebelum dan sesudah yang diperoleh akan di olah dan melakukan analisa data.

\section{HASIL DAN PEMBAHASAN}

Pada penelitian kelompok feldenkrais exercise didapatkan hasil yang cukup signifikan dilihat dari hasil rerata menunjukan nilai penurunan nilai ODI dimana hasil itu berarti terjadi peningkatan aktivitas fungsional yang cukup signifikan dilihat dari hasil uji paired sampel t-test. Hal tersebut sejalan dengan penelitian sebelumnya yang dilakukan oleh Ohman pada tahun 2011 yang memiliki kesamaan tujuan perlakuan feldenkrais exercise untuk melihat peningkatan aktivitas fungsional pada LBP, dimana dalam penelitian tersebut terjadi peningkatan aktifitas fungsional yang cukup signifikan pada orang dengan LBP. Pada penelitian sebelumnya dilakukan dalam waktu 6 minggu dengan frekuensi sekali dalam satu minggu durasi latihan 90 menit. Dalam penelitian ini dilakukan dalam waktu 5 
minggu dengan dua kali dalam satu minggu dengan durasi latihan 45 menit mendapatkan hasil yang sama signifikannya terhadap peningkatan aktivitas fungsional pada LBP. Peningkatan aktivitas fungsional dievaluasi setelah dilakukan intervensi selama 5 minggu. Evaluasi tidak dilakukan pada minggu pertama, kedua, ketiga, dan keempat. Dapat disimpulkan bahwa, intensitas pertemuan yang lebih sering dilakukan membuat latihan lebih efektif. Hal ini dikarenakan adaptasi terhadap jaringan otot akan menjadi lebih cepat dikarenakan latihan dilakukan dengan jeda waktu yang lebih pendek sehingga otot akan lebih cepat relaksasi setelah sebelumnya mengalami tegang.

Pada intervensi dengan Feldenkrais exercise yang dilakukan pada posisi tidur terlentang dan tengkurap yang membuat otot rileks sehingga efek yang terjadi setelah dilakukannya latihan ini, konektivitas antar jaringan pada pinggang menjadi lebih baik, sehingga postur setelah diberikan latihan ini akan menjadi lebih baik. Berdasarkan hasil uji t-test pada kelompok Feldenkrais exercise didapatkan nilai mean 8,125 dengan $p$ value 0,000 sehingga kesimpulan yang didapat adalah terdapat perbedaan yang signifikan pada kelompok ini.
Pada kelompok dengan perlakuan William flexion exercise didapatkan hasil perubahan yang signifikan, dilihat dari hasil rerata sebesar 3,25 menunjukan nilai penurunan ODI dimana hasil tersebut menunjukan terdapat peningkatan aktivitas fungsional pada seseorang dengan keluhan LBP miogenik yang cukup signifikan. Hal ini dibuktikan dengan hasil nilai $p$-value pada kelompok perlakuan William flexion exercise sebesar 0,000. Hasil ini didukung oleh penelitian sebelumnya yang dilakukan oleh Paramita pada tahun 2014 yang menunjukkan bahwa william flexion exercise meningkatkan mobilitas lumbal dan aktivitas fungsional pada pasien LBP miogenik. William flexion exercise memiliki prinsip rileksasi otot paravertebrae yang merupakan global muscle yang berfungsi sebagai penggerak fleksi dan ekstensi trunk. Pada pasien LBP miogenik terjadi spasme pada otot paravertebrae, dengan latihan ini otot tersebut menjadi rileks sehingga mobilitas fleksi dan ekstensi trunk meningkat, nyeri berkurang dan aktivitas fungsional meningkat.

Pada hasil penghitungan akhir dilakukan uji independent sampel t-test untuk melihat perbandingan perbedaan hasil dari 
13 Jurnal Ilmu dan Teknologi Kesehatan, Vol 6 Nomor 1, September 2018, hlm : 8 - 14

kedua perlakuan yang digunakan. Hasil uji dilihat pada tabel berikut.

independent $t$-test pada penelitian ini dapat

Tabel 1. Hasil Uji T-test Kelompok Feldenkrais dan William Flexion

\begin{tabular}{lcc}
\hline \multicolumn{1}{c}{ Kelompok } & Mean & p-value \\
\hline Feldenkrais exercise & 8,13 & \multirow{2}{*}{0,000} \\
William flexion exercise & 3,25 & \\
\hline
\end{tabular}

Berdasarkan tabel hasil uji independent $t$ test di atas, didapatkan kesimpulan bahwa terdapat perbedaan pengaruh yang signifikan pada kedua kelompok perlakuan. Hal ini ditunjukkan oleh nilai p-value pada penelitian ini $<0,05$ yaitu sebesar. 0,000. Selain itu, berdasarkan nilai rerata pada uji independent sampel t-test maka kelompok perlakuan pertama dengan intervensi feldenkrais exercise menunjukkan nilai rerata 8,13 dan kelompok perlakuan kedua dengan intervensi william flexion exercise menunjukkan nilai rerata 3,25 maka dengan demikian dapat disimpukan bahwa hasil yang lebih efektif terhadap peningkatan aktifitas fungsional pasien dengan LBP miogenik terdapat pada perlakuan feldenkrais exercise.

Hal ini dikarenakan feldenkrais exercise memiliki prinsip utama saat mengaplikasikan teknik tersebut yaitu dilakukan secara perlahan, memperhatikan dan merasakan sensasi gerakan yang dilakukan, lakukan dengan gerakan yang benar, memperhatikan pola nafas dengan teratur dan dilakukan pada posisi otot dalam keadaan rileks. Pada hasil diatas menunjukan bahwa dari segi efek fisiologis menunjukkan bahwa feldenkrais exercise lebih baik karena latihan ini dapat mengaktifkan otot bagian dalam dari back ekstensor sehingga sinergitas otot lebih baik, maka dengan demikian otot yang sering mengalami spasme dapat bekerja lebih ringan. Sedangkan pada perlakuan william flexion exercise mekanisme yang digunakan adalah streching maka sesaat setelah diberikan latihan ini seseorang akan merasa lebih baik, namun karena tidak ada aktivasi otot lain maka dalam jangka waktu yang tertentu dengan intensitas kegiatan yang berlebihan resiko LBP miogenik akan timbul kembali.

\section{SIMPULAN}

Berdasarkan hasil yang diperoleh pada penelitian ini maka dapat disimpulkan sebagai berikut: Pertama, terjadi peningkatan aktivitas fungsional yang signifikan pada orang dengan Low Back 
Yuda S dan Ahmad S, Feldenkrais Exercise Mempangaruhi Peningkatan Aktivitas Fungsional Lebih

Pain Miogenik setelah diberikan intervensi

Feldenkrais Exercise. Kedua, terjadi peningkatanbaktivitas fungsional yang signifikan pada orang dengan Low Back Pain Miogenik setelah diberikan intervensi William Flexion Exercise. Ketiga, terdapat perbedaan pengaruh yang signifikan antara Feldenkrais Exercise dan William Flexion Exercise dalam meningkatkan aktivitas fungsional pada orang dengan Low Back Pain Miogenik dimana Feldenkrais Exercise lebih baik dibanding William Flexion Exercise.

\section{DAFTAR RUJUKAN}

Balter, J. E. (2013). Mechanical Pain Sensitivity And The Severity Of Chronic Neck Pain And Disability Are Not Modulated Across The Menstrual Cycle. National Institutes of Health Public Access ,1-17.

Dabholkar, T.A., Nakhawa, P. \& Yardi, S.,2014. Common musculoskeletal problem experienced by fishing industry workers, 18(2).Available at: http://pubmedcentralcanada.ca/pmcc/ ar ticles/PMC4280776/.

Duthey, B., 2013. Background Paper 6.24Low back pain. Priority Medicines for Europe and the World. Global Burden of Disease (2010), (March), pp.1-29.

Farasyn, A. (2007). Pressure Pain Algometry in Patients with NonSpecific Low Back Pain. Faculty of Physical Education and
Physiotherapy Department of Human Physiology \& Sports Medicine.

Feldenkrais, Moshe.,1987. Awareness Through Movement. England. Penguin Books Ltd.

Fonow Et. Al., 2016. Using the Feldenkrais Method of Somatic Education to Enhance Mindfulness, Body Awareness, and Empathetic Leadership Perceptions Among College Students. Available at: DOI:

1012806/V1/I3/R4

Lee, J. Et Al., 2016. Comparison Of Three Different Surface Plank Exercises On Core Muscle Activity. Physical Therapy Rehabilitation Science, 5 (1), Pp.2933.

Mohan, Vikram Et Al., 2016. Feldenkrais method on neck and low back pain to the type of exercises and outcome

measurement tools: A systematic review. Thailand. Neuro- Musculoskeletal and Pain Research Unit, Department of Physical Therapy, Faculty of Associated Medical Sciences, Chiang Mai University

Pramita, I., 2014. Core stability exercise Lebih Baik Meningkatakan Aktivitas Fungsional Dari Pada William Flexion Exercise Pada Pasien Nyeri Punggung Bawah Miogenik. Denpasar.

Sherwood, 1. (2009). Fisiologi Manusia Dari Sel Ke Sistem. Edisi 6. Jakarta: Penerbit Buku Kedokteran EGC 